\title{
The effects of fluid penetration and interfacial porosity on the fixation of cemented femoral components
}
K. Iesaka, W. L. Jaffe, C. M. Jones, F. J. Kummer

From the New York University Hospital for Joint Diseases, New York, USA

K. lesaka, MD, Orthopaedic Research Fellow

F. J. Kummer, PhD, Associate Director

Musculoskeletal Research

Center

W. L. Jaffe, MD,

Orthopaedic Surgeon,

Clinical Professor

Department of Orthopaedic Surgery

New York University Hospital for Joint Diseases, 301 E 17th Street, New York, 10003,

USA.

C. M. Jones, MD,

Orthopaedic Resident

University of Miami School

of Medicine

Jackson Memorial Hospital, 1611 N. W. 12th Avenue,

Miami, Florida 33136-1094, USA.

Correspondence should be sent to Dr K. lesaka; e-mail: kazuho@biomech.org

(C)2005 British Editorial

Society of Bone and

Joint Surgery

doi:10.1302/0301-620X.87B9.

$15404 \$ 2.00$

$J$ Bone Joint Surg [Br]

2005;87-B:1298-1302.

Received 16 February 2004;

Accepted after revision

3 February 2005

\begin{abstract}
We have investigated the role of the penetration of saline on the shear strength of the cement-stem interface for stems inserted at room temperature and those preheated to $37^{\circ} \mathrm{C}$ using a variety of commercial bone cements. Immersion in saline for two weeks at $37^{\circ} \mathrm{C}$ reduced interfacial strength by $56 \%$ to $88 \%$ after insertion at room temperature and by $28 \%$ to $49 \%$ after preheating of the stem. The reduction in porosity as a result of preheating ranged from $71 \%$ to $100 \%$. Increased porosity correlated with a reduction in shear strength after immersion in saline $(r=0.839, p<0.01)$ indicating that interfacial porosity may act as a fluid conduit.
\end{abstract}

Debonding of the cement-stem interface, followed by failure of the cement mantle, has been implicated as a cause of aseptic failure in cemented total hip arthroplasty. ${ }^{1-15}$ Previous studies have found that debonding of the cement-stem interface is likely to initiate failure of the cement mantle and may provide a pathway for wear debris to migrate distally. ${ }^{14,16-18}$ Clinical studies have shown that polished implants with early signs of debonding of the cement-stem interface have a higher rate of loosening than stems with no debonding. ${ }^{9,19}$ Retrieval studies have also reported that debonding may occur soon after implantation. ${ }^{10,20-22}$ Laboratory studies have shown that the shear strength of the cement-stem interface decreases under physiological conditions by more than $60 \%$ after 24 hours and by more than $80 \%$ after two months. ${ }^{23-25}$ The mechanism of this deterioration is unknown, although penetration of fluid into the interface and stress relaxation of the cement have been implicated.

Our aim was to investigate the effect of the penetration of fluid on the strength of the cement-stem interface and the consequence of reducing interfacial porosity.

\section{Materials and Methods}

Preparation of specimens. The experimental model was designed to simulate in vivo surgical insertion of the stem using comparable materials of similar dimensions and appropriate cementing techniques (Fig. 1). ${ }^{26}$ Cobaltchromium cylinders $140 \mathrm{~mm}$ long and $126 \mathrm{~mm}$ in diameter with rounded ends and a surface

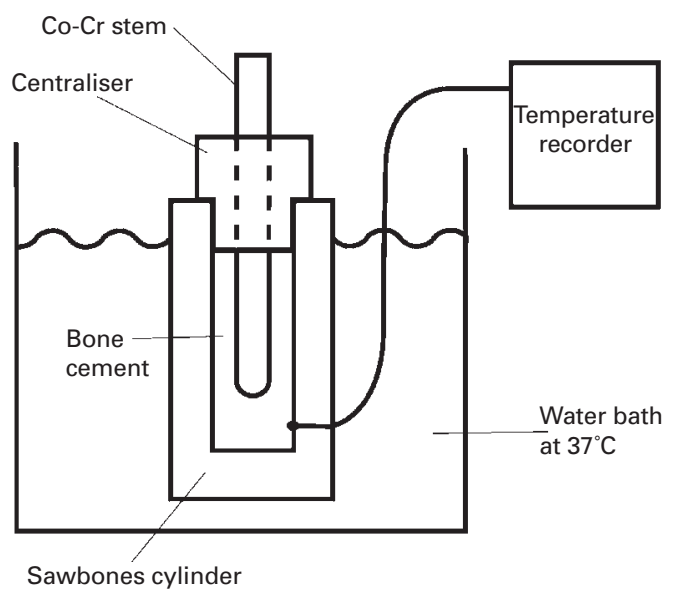

Fig. 1

Diagram of the experimental apparatus.

roughness of $0.889 \mu \mathrm{m}$, were used to simulate femoral stems. Sawbones cylinders (Pacific Research Laboratories, Vashon, Washington) 40 pounds per cubic feet, $36 \mathrm{~mm}$ in diameter and $75 \mathrm{~mm}$ long with a cavity $20 \mathrm{~mm}$ in diameter and $60 \mathrm{~mm}$ deep were used to simulate femora. The preheated stems were held at $37^{\circ} \mathrm{C}$ for a minimum of one hour in a temperaturecontrolled oven (Isotemp Lab Oven 106G; Fisher Scientific, Pittsburgh, Pennsylvania) before use. ${ }^{26}$ A custom-built centraliser was used during polymerisation to control the stem and to produce a uniform, cement mantle $4 \mathrm{~mm}$ thick and $10 \mathrm{~mm}$ long, beyond the tip of the stem. In order to determine the maximum polymerisation temperature a thermocouple (Model 5TC-GG-J-20-36; Omega Engineering 
Table I. Details of the results given as the mean (SD)

\begin{tabular}{|c|c|c|c|c|c|c|c|}
\hline \multirow[b]{2}{*}{ Cement } & \multirow[b]{2}{*}{$\begin{array}{l}\text { Initial stem } \\
\text { temperature }\end{array}$} & \multirow{2}{*}{$\begin{array}{l}\text { Maximum } \\
\text { polymerisation } \\
\text { temperature } \\
\left({ }^{\circ} \mathrm{C}, \mathrm{n}=8\right)\end{array}$} & \multirow[b]{2}{*}{$\begin{array}{l}\text { Polymerisation } \\
\text { time } \\
\text { (min, } \mathbf{n = 8} \text { ) }\end{array}$} & \multicolumn{3}{|c|}{ Shear strength of cement-stem interface } & \multirow{2}{*}{$\begin{array}{l}\text { Porosity at the } \\
\text { cement-stem } \\
\text { interface } \\
(\% \text { area, } n=8)\end{array}$} \\
\hline & & & & $\begin{array}{l}\text { Immediately tested } \\
(\mathrm{MPa}, \mathrm{n}=80)\end{array}$ & $\begin{array}{l}\text { After } 2 \text { weeks } \\
\text { in } 37^{\circ} \mathrm{C} \text { saline } \\
(\mathrm{MPa}, \mathrm{n}=8)\end{array}$ & $\begin{array}{l}\text { After } 2 \text { weeks } \\
\text { in } 37^{\circ} \mathrm{C} \text { air } \\
(\mathrm{MPa}, \mathrm{n}=8)\end{array}$ & \\
\hline \multirow[t]{2}{*}{ Depuy 1} & Room temperature & $49.9(2.7)$ & $6.9(0.4)$ & $0.92(0.19)$ & $0.14(0.06)$ & $1.20(0.39)$ & $35.6(20.8)$ \\
\hline & $37^{\circ} \mathrm{C}$ & $52.3(4.3)$ & $5.9(0.8)$ & $1.68(0.25)$ & $0.81(0.23)$ & $1.57(0.41)$ & $0.8(0.8)$ \\
\hline \multirow[t]{2}{*}{ Depuy 3} & Room temperature & $50.1(4.1)$ & $7.5(0.5)$ & $0.93(0.12)$ & $0.47(0.21)$ & $1.07(0.23)$ & $19.4(12.7)$ \\
\hline & $37^{\circ} \mathrm{C}$ & $53.9(3.3)$ & $6.4(0.5$ & $1.27(0.25)$ & $0.98(0.24)$ & $1.45(0.19)$ & $0.1(0.1)$ \\
\hline \multirow[t]{2}{*}{ Osteobond } & Room temperature & $50.1(3.2)$ & $7.9(0.8)$ & $1.18(0.13)$ & $0.17(0.06)$ & $1.01(0.30)$ & $45.8(4.4)$ \\
\hline & $37^{\circ} \mathrm{C}$ & $51.8(3.3)$ & $7.3(1.0)$ & $1.88(0.12)$ & $1.36(0.19)$ & $1.79(0.18)$ & $0.1(0.1)$ \\
\hline \multirow[t]{2}{*}{ Palacos R } & Room temperature & $47.5(3.7)$ & $7.3(0.5)$ & $0.59(0.12)$ & $0.14(0.11)$ & $0.70(0.30)$ & $50.5(10.5)$ \\
\hline & $37^{\circ} \mathrm{C}$ & $50.6(1.8)$ & $6.6(0.5)$ & $1.39(0.47)$ & $1.13(0.31)$ & $1.60(0.30)$ & $14.6(4.9)$ \\
\hline \multirow[t]{2}{*}{ Simplex $P$} & Room temperature & $47.8(3.6)$ & $7.6(0.7)$ & $1.38(0.18)$ & $0.44(0.11)$ & $1.46(0.47)$ & $15.8(3.2)$ \\
\hline & $37^{\circ} \mathrm{C}$ & $54.3(2.8)$ & $6.4(0.7)$ & $1.84(0.28)$ & $1.24(0.22)$ & $1.75(0.28)$ & $0.1(0.2)$ \\
\hline
\end{tabular}

Inc., Stamford, Connecticut) was placed at the cement-bone interface $5 \mathrm{~mm}$ from the bottom of the cement mantle. This had been established previously to be the optimal position for measuring the maximum polymerisation temperature.

The Sawbones cylinders were held in a water bath at $37^{\circ} \mathrm{C}$ for one hour before and during, polymerisation of cement. Five types of commercially-available bone cement were used: Depuy 1 (CMW 1; Depuy Orthopaedics, Warsaw, Indiana) and Depuy 3 (CMW3; Depuy Orthopaedics); Osteobond (Zimmer, Warsaw, Indiana) Palacos R (Biomet Orthopedics, Warsaw, Indiana); and Simplex P (StrykerHowmedica-Osteonics, Mahwah, New Jersey). They were mixed for 90 seconds using a vacuum mixing system (Stryker-Howmedica-Osteonics) and then injected in a retrograde manner using a cement gun (Stryker-Howmedica-Osteonics). Two specimens were prepared from each package of bone cement. The stem was inserted three minutes after the initiation of cement mixing. The temperature at the cement-bone interface was measured using a chart recorder (Omegaline 790; Omega Engineering Inc.) for 20 minutes after insertion of the stem. The setting time was defined as the time from insertion of the stem until one minute after the maximum temperature had been reached. ${ }^{27}$

The sheer strength of the cement-stem interface was tested after one of three ageing conditions: immediately after cement polymerisation, after immersion for two weeks in normal saline at $37^{\circ} \mathrm{C}$ and after storage in air at $37^{\circ} \mathrm{C}$ for two weeks. For each type of cement, eight specimens were tested for each ageing condition. The polymerisation temperatures were recorded for the eight specimens which had been tested immediately. During the experiment the room temperature ranged from $19^{\circ} \mathrm{C}$ to $22^{\circ} \mathrm{C}$.

Test methods. For static testing, the cement mantle and surrounding material were machined to create rings $20 \mathrm{~mm}$ thick with the base located $10 \mathrm{~mm}$ proximal to the tip of the stem. The stem distal to this was inserted into an aluminium block with a hole $12.7 \mathrm{~mm}$ in diameter. The free end of the stem was loaded in a MTS servohydraulic testing machine (MTS Systems, Eden Prairie, Minnesota) at a rate of $0.3 \mathrm{~mm} / \mathrm{sec}$ using a self-centering proximal stem holder to ensure true axial loading with minimal side loads. Compression ('push-out') tests were performed to determine the shear strength of the cement-stem interface. Failure was defined as a marked drop in load or when a displacement of the cement mantle of $1 \mathrm{~mm}$ had occurred along the stem.

Distribution of porosity. After mechanical testing, the cement mantle of every specimen which had been tested immediately was carefully removed and cut into longitudinal sections. Eight specimens of each group were prepared for the measurement of porosity. The pores on the interface were highlighted using black ink. The specimens were then photographed using a digital camera (Finepix 4700Z; Fujifilm, Tokyo, Japan) and analysed using Photoshop v. 7.0 (Adobe Systems Inc., San Jose, California) and NIH Image (National Institutes of Health, Bethesda, Maryland) to determine the percentage porosity at the cement-stem interface.

Statistical analysis. In order to analyse the effect of the temperature of the stem on the polymerisation time and temperature at the cement-bone interface, a two-way ANOVA for independent samples was done with one factor being the temperature of the stem and the other the type of cement. For the analysis of porosity a two-way ANOVA for independent samples was done with one factor being the temperature of the stem and the other the type of cement. In order to analyse the effect of the temperature of the stem on shear strength after one of three ageing conditions, a twoway ANOVA for independent samples with a post hoc Tukey test was performed for each type of cement, with one factor being the temperature of the stem and the other the ageing condition. Statistical significance was set at $\mathrm{p}<0.05$.

\section{Results}

Polymerisation time and temperature at the cement-bone interface. The mean (SD) polymerisation times and maximum temperatures during polymerisation are shown in Table I. The mean polymerisation time of the preheated stems was significantly shortened by $8 \%$ to $15 \%$ ( $p=7.42$ $\mathrm{x} 10^{-8}$ ) and the mean maximum temperature at the cementbone interface was significantly elevated by $2.4^{\circ} \mathrm{C}$ to $6.5^{\circ} \mathrm{C}$ $\left(\mathrm{p}=1.52 \times 10^{-5}\right)$ compared with the stems at room temper- 


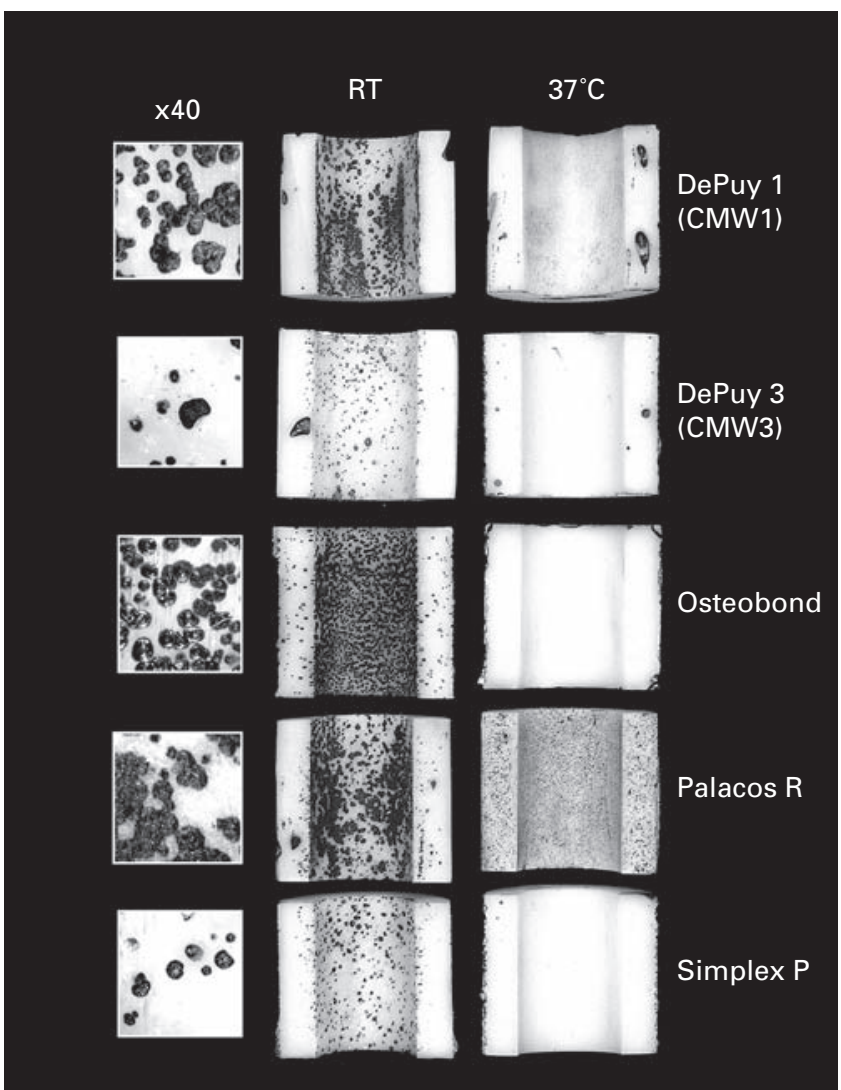

Fig. 2

Longitudinal sections of the cement mantle for the different types of cement. There are pores at the cement-stem interface. The column headings are as follows: $\times 40$, magnified view of corresponding section at room temperature; $\mathrm{RT}$, at room temperature; $37^{\circ} \mathrm{C}$, preheated to $37^{\circ} \mathrm{C}$ immediately before insertion.

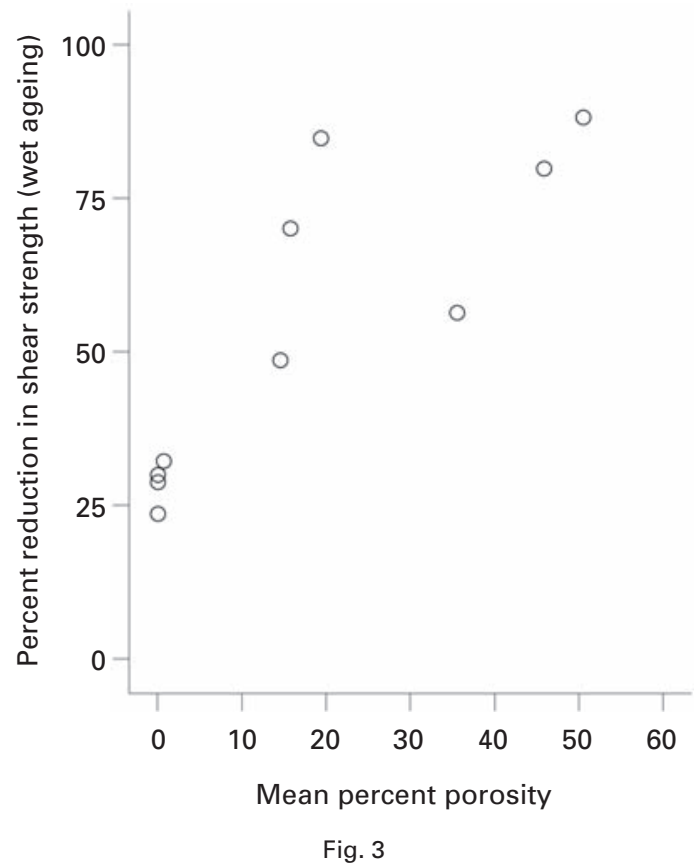

The effect of saline after ageing for two weeks at $37^{\circ} \mathrm{C}$. Each symbol represents the mean of the specimens in the group. ature. Osteobond bone cement showed no changes in polymerisation time or maximum temperature.

Distribution of porosity. Every specimen in the room temperature group showed extensive porosity at the cementstem interface (Fig. 2, Table I), although the amount of porosity and the appearance of the pores varied between the types of bone cement. The mean porosity at the cementstem interface significantly decreased when the stem was preheated $\left(\mathrm{p}=1.72 \times 10^{-30}\right)$. This reduction in porosity varied from $71.1 \%$ to $99.8 \%$ depending upon the type of cement. While preheating usually eliminated more than $99 \%$ of interfacial porosity, specimens in the Palacos R group with heated stems and the Depuy 1 group with heated stems showed tiny pores at the cement-stem interface and within the cement mantle. In Palacos R specimens these pores were distributed evenly throughout the cement mantle.

Shear strength of the cement-stem interface. For all types of cement, the mean shear strength of the cement-stem interface significantly increased in all preheated stems compared with those at room temperature regardless of the ageing condition (CMW 1, p = 4.52 × 10 $0^{-9}$; CMW3, $\mathrm{p}=3.25 \times 10^{-8}$; Osteobond, $\mathrm{p}=7.97 \times 10^{-21}$; Palacos $\mathrm{R}, \mathrm{p}=2.32 \times 10^{-13}$; Simplex P, p = $1.04 \times 10^{-7}$; Table I). After two weeks of immersion in isotonic saline at $37^{\circ} \mathrm{C}$, the mean shear strength was significantly lower than that immediately after polymerisation $\left(\mathrm{CMW} 1, \mathrm{p}=5.96 \times 10^{-9} ; \mathrm{CMW} 3, \mathrm{p}=2.58\right.$ x $10^{-5}$; Osteobond, $\mathrm{p}=5.10 \times 10^{-9} ;$ Palacos $\mathrm{R}, \mathrm{p}=0.00396$; Simplex P, $p=9.11 \times 10^{-9}$; Table I). The shear strength was the same or only slightly higher after ageing in air at $37^{\circ} \mathrm{C}$ than immediately after polymerisation (CMW $1, \mathrm{p}=0.644$; CMW3, $\mathrm{p}=0.0852$; Osteobond, $\mathrm{p}=0.109$; Palacos R, $\mathrm{p}=0.273$; Simplex $\mathrm{P}, \mathrm{p}=0.997$ ).

The difference in the mean shear strength after two weeks of immersion in saline at $37^{\circ} \mathrm{C}$ and after two weeks of ageing in air at $37^{\circ} \mathrm{C}$ was statistically significant for all types of

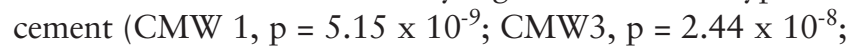
Osteobond, $\mathrm{p}=5.10 \times 10^{-9}$; Palacos R, $\mathrm{p}=3.33 \times 10^{-5}$; Simplex $\left.\mathrm{P}, \mathrm{p}=1.03 \times 10^{-8}\right)$. There was a positive correlation between the mean loss of shear strength because of immersion in saline (calculated using air-aged specimens as a baseline) and the mean area percentage of interfacial porosity $\left(r=0.839, r^{2}=0.704, y=34.5+2.48 x, p=0.00239\right.$; Fig. 3$)$.

\section{Discussion}

The cement-stem interfacial shear strength decreased dramatically after immersion for only two weeks in saline at $37^{\circ} \mathrm{C}$, a finding consistent with previous reports, ${ }^{23-25}$ whereas it stayed the same or was slightly increased in specimens aged for the same period in air at $37^{\circ} \mathrm{C}$. Since specimens in both the wet-ageing and dry-ageing groups were kept at the same temperature $\left(37^{\circ} \mathrm{C}\right)$, polymerisation shrinkage and stress relaxation of the cement mantles should have occurred to the same extent. ${ }^{28-30}$ In a study of the effects of ageing on bulk cement, Jaffe, Rose and Radin ${ }^{31}$ immersed specimens in bovine serum at $37^{\circ} \mathrm{C}$ for 
two years and found no appreciable deterioration either in static properties or in compression fatigue behaviour. Thus, our results suggest that the decrease in shear strength which we observed in wet ageing arose from the penetration of saline into the interface rather than from stress relaxation or degradation of the cement itself. It is important to note that this penetration of fluid occurred without cyclic loading or fluid pressurisation.

While preheating of the stem eliminated most interfacial porosity of the cement-stem interface, interfacial porosity was still observed in the Palacos $\mathrm{R} 37^{\circ} \mathrm{C}$ group and Depuy $137^{\circ} \mathrm{C}$ group. The source of these pores was not clear. They appeared evenly on the interface and within the cement mantle. Both cements are high-viscosity types and therefore these pores probably came from microscopic air bubbles trapped during mixing of the cement which the vacuummixing system could not eliminate.

A significant correlation was found between the amount of interfacial porosity and the reduction in shear strength after ageing in $37^{\circ} \mathrm{C}$ saline. Preheating the stem eliminates interfacial porosity, resulting in a seal which prevents penetration of fluid. Other important effects of preheating stems such as an increase in shear strength of the cementstem interface, a slightly-shortened polymerisation time and slightly-elevated polymerisation temperature at the cement-bone interface, ${ }^{26,32}$ occurred in our specimens of bone cement.

As previously reported, the increase in temperature during polymerisation at the cement-bone interface with stems preheated to $37^{\circ} \mathrm{C}$ is probably too low to produce thermal necrosis of adjacent host bone. ${ }^{26,32,33}$ Bishop et $\mathrm{al}^{32}$ reported no increase in polymerisation temperature with Palacos $\mathrm{R}$ bone cement using cadaver femora and stems preheated to $44^{\circ} \mathrm{C}$.

Several investigators have suggested that interfacial porosity results from the formation of air bubbles during insertion of the stem. ${ }^{34,35}$ Our findings indicate that the major cause of the formation of interfacial porosity is more likely to be polymerisation shrinkage which is approximately $2 \%$ to $7 \%$ by volume. ${ }^{26,32,36,37}$

Increased shear strength of the cement-stem interface is expected when matte/porous-coated stems are used since these types of stem are designed to provide high bonding strength at the cement-stem interface. Strong bonding at the interface minimises stress in the cement mantle and prevents its failure. ${ }^{1,15,38,39}$ For polished, tapered stems, increased shear strength may not be as important. However, it is known that polished surfaces may provide higher friction of forces than matte surfaces. ${ }^{40,41} \mathrm{~A}$ strengthened cement-stem interface and the use of a polished stem may not be mutually exclusive. The effects of reduced interfacial porosity are not only increased shear strength but better sealing of the cement-stem interface and the reduction of interfacial porosity which could initiate cement cracks. Better sealing of the cement-stem interface may prevent migration of wear debris and thus may lower the risk of osteolysis for both matte and polished stems. ${ }^{14,16-18}$ Thus, preheating of the stem may be useful for both matte and polished stems.

Finally, it should be noted that the size, shape, and appearance of the interfacial pores varied according to the type of bone cement. The cause of this variation was unclear. It may have been due to differences in additives such as radiopaque agents, catalyst inhibitors, cement particles of distribution size, the chemical composition and differences in the ratio of monomer to polymer.

Although we tried to simulate the clinical situation and materials, there are several limitations of our study. Only one type of material, shape, surface finnish and mixing device was used. Bone cement was stored at room temperature before use, but some surgeons prefer to chill it, especially for high-viscosity bone cement such as Palacos $\mathrm{R}$ and Depuy 1 (CMW 1). Micropores of less than $50 \mu \mathrm{m}$ in diameter were not accounted for because of the resolution of the imaging techniques.

Our results show, however, that the rapid reduction in shear strength at the cement-stem interface during immersion in fluid is likely to be due to the penetration of fluid into the interface. A porosity-free cement-stem interface appears to provide a better seal against this penetration of fluid. Preheating stems to $37^{\circ} \mathrm{C}$ before insertion eradicates all or nearly all of the pores and results in a greater interface shear strength than that seen in stems inserted without preheating.

No benefits in any form have been received or will be received from a commercial party related directly or indirectly to the subject of this article.

\section{References}

1. Harrigan TP, Harris WH. A three-dimensional non-linear finite element study of the effect of cement-prosthesis debonding in cemented femoral total hip components. J Biomech 1991;24:1047-58.

2. Gruen TA, McNeice GM, Amstutz HC. "Modes of failure" of cemented stem-type femoral components: a radiographic analysis of loosening. Clin Orthop 1979;141:17-27.

3. Older J. Low-friction arthroplasty of the hip: a 10-12-year follow-up study. Clin Orthop 1986;211:36-42.

4. Stauffer RN. Ten-year follow-up study of total hip replacement. J Bone Joint Surg [Am] 1982;64-A:983-90.

5. Sutherland CJ, Wilde AH, Borden LS, Marks KE. A ten-year follow-up of one hundred consecutive Muller curved-stem total hip-replacement arthroplasties. J Bone Joint Surg [Am] 1982;64-A:970-82.

6. Weber FA, Charnley J. A radiological study of fractures of acrylic cement in relation to the stem of a femoral head prosthesis. J Bone Joint Surg [Br] 1975;57-B:297-301.

7. Wroblewski BM. 15-21-year results of the Charnley low-friction arthroplasty. Clin Orthop 1986;211:30-5.

8. Halley DK, Wroblewski BM. Long-term results of low-friction arthroplasty in patients 30 years of age or younger. Clin Orthop 1986;211:43-50.

9. Berry DJ, Harmsen WS, Ilstrup DM. The natural history of debonding of the femoral component from the cement and its effect on long-term survival of Charnley total hip replacements. J Bone Joint Surg [Am] 1998;80-A:715-21.

10. Jasty M, Maloney WJ, Bragdon CR, et al. The initiation of failure in cemented femoral components of hip arthroplasties. J Bone Joint Surg [Br] 1991;73-B:551-8.

11. Massoud SN, Hunter JB, Holdsworth BJ, Wallace WA, Juliusson R. Early femoral loosening in one design of cemented hip replacement. J Bone Joint Surg $[\mathrm{Br}]$ 1997;79-B:603-8.

12. Mohler CG, Callaghan JJ, Collis DK, Johnston RC. Early loosening of the femora component at the cement-prosthesis interface after total hip replacement. J Bone Joint Surg [Am] 1995;77-A:1315-22.

13. Muller RT, Heger I, OIdenburg M. The mechanism of loosening in cemented hip prostheses determined from long-term results. Arch Orthop Trauma Surg 1997:116:41-5. 
14. Verdonschot $\mathbf{N}$, Huiskes R. The effects of cement-stem debonding in THA on the long-term failure probability of cement. J Biomech 1997;30:795-802.

15. Crowninshield RD, Tolbert JR. Cement strain measurement surrounding loose and well-fixed femoral component stems. J Biomed Mater Res 1983;17:819-28.

16. Schmalzried TP, Jasty M, Harris WH. Periprosthetic bone loss in total hip arthroplasty: polyethylene wear debris and the concept of the effective joint space. J Bone Joint Surg [Am] 1992;74-A:849-63.

17. Schmalzried TP, Kwong LM, Jasty M, et al. The mechanism of loosening of cemented acetabular components in total hip arthroplasty: analysis of specimens retrieved at autopsy. Clin Orthop 1992;274:60-78.

18. Maloney WJ, Jasty M, Rosenberg A, Harris WH. Bone lysis in well-fixed cemented femoral components. J Bone Joint Surg [Br] 1990;72-B:966-70.

19. Karrholm J, Borssen B, Lowenhielm G, Snorrason F. Does early micromotion of femoral stem prostheses matter: 4-7-year stereoradiographic follow-up of 84 cemented prostheses. J Bone Joint Surg [Br] 1994;76-B:912-17.

20. Fornasier VL, Cameron HU. The femoral stem/cement interface in total hip replacement. Clin Orthop 1976;116:248-52.

21. Raab S, Ahmed AM, Provan JW. Thin film PMMA precoating for improved implant bone-cement fixation. J Biomed Mater Res 1982;16:679-704.

22. Raab S, Ahmed AM, Provan JW. The quasistatic and fatigue performance of the implant/bone-cement interface. J Biomed Mater Res 1981;15:159-82

23. Muller RT, Schurmann N. Shear strength of the cement metal interface: an experimental study. Arch Orthop Trauma Surg 1999;119:133-8.

24. Ahmed AM, Raab S, Miller JE. Metal/cement interface strength in cemented stem fixation. J Orthop Res 1984;2:105-18.

25. Ohashi KL, Dauskardt RH. Effects of fatigue loading and PMMA precoating on the adhesion and subcritical debonding of prosthetic-PMMA interfaces. J Biomed Mater Res 2000;51:172-83.

26. lesaka K, Jaffe WL, Kummer FJ. Effects of preheating of hip prostheses on the stem-cement interface. J Bone Joint Surg [Am] 2003;85-A:421-7.

27. Debrunner HU, Wettstein A, Hofer $\mathbf{P}$. The polymerization of self-curing acrylic cements and problems due to the cement anchorage of joint prosthesis. In: Schaldach M, Hohmann D, eds. Artificial hip and knee joint technology. Berlin: Springer-Verlag, 1976:294-324.
28. Lennon AB, Prendergast PJ. Residual stress due to curing can initiate damage in porous bone cement: experimental and theoretical evidence. J Biomech 2002;35: 311-21.

29. Ahmed AM, Pak W, Burke DL, Miller J. Transient and residual stresses and displacements in self-curing bone cement. Part l: characterization of relevant volumetric behavior of bone cement. J Biomech Eng 1982;104:21-7

30. Ahmed AM, Nair R, Burke DL, Miller J. Transient and residual stresses and displacements in self-curing bone cement. Part II: thermoelastic analysis of the stem fixation system. J Biomech Eng 1982:104:28-37.

31. Jaffe WL, Rose RM, Radin EL. On the stability of the mechanical properties of selfcuring acrylic bone cement. J Bone Joint Surg [Am]1974;56-A:1711-14.

32. Bishop NE, Ferguson S, Tepic S. Porosity reduction in bone cement at the cementstem interface. J Bone Joint Surg [Br] 1996;78-B:349-56.

33. Liu C, Green SM, Watkins ND, Gregg PJ, McCaskie AW. Some failure modes of four clinical bone cements. Proc Inst Mech Eng [H] 2001;215:359-66.

34. James SP, Schmalzried TP, McGarry FJ, Harris WH. Extensive porosity at the cement-femoral prosthesis interface: a preliminary study. J Biomed Mater Res 1993; 27:71-8.

35. Baleani M, Fognani R, Toni A. The influence of stem insertion rate on the porosity of the cement mantle of hip joint replacements. Proc Inst Mech Eng [H] 2003;217: $199-205$

36. Dunne NJ, Orr JF, Mushipe MT, Eveleigh RJ. The relationship between porosity and fatigue characteristics of bone cement. Biomaterials 2003;24:239-45.

37. Gilbert JL, Hasenwinkel JM, Wixson RL, Lautenschlager EP. A theoretical and experimental analysis of polymerization shrinkage of bone cement: a potential major source of porosity. J Biomed Mater Res 2000;52:210-18.

38. Verdonschot $\mathbf{N}$, Huiskes R. Subsidence of THA stems due to acrylic cement creep is extremely sensitive to interface friction. J Biomech 1996;29:1569-75.

39. Verdonschot $\mathbf{N}$, Huiskes R. Mechanical effects of stem cement interface characteristics in total hip replacement. Clin Orthop 1996;329:326-36.

40. Rabinowicz E. Quantitative laws of sliding friction. In: Rabinowicz $\mathrm{E}$, ed. Friction and wear of materials. Second ed. New York: John Wiley \& Sons Inc., 1995:66-74.

41. Bundy KJ, Penn RW. The effect of surface preparation on metal/bone cement interfacial strength. J Biomed Mater Res 1987;21:773-805. 